\title{
Fibular Shaft
}

National Cancer Institute

\section{Source}

National Cancer Institute. Fibular Shaft. NCI Thesaurus. Code C120670.

The elong ated bony body of a fibula compressing of the anterior, posterior, internal and external surfaces separated by the anteroexternal, anterointernal, posteroexternal and posterointernal borders. 